\title{
Effect of Zn on Microstructures and Properties of Mg-Zn Alloys Prepared by Powder Metallurgy Method
}

\author{
Yu Jingyuan", ${ }^{1,2} \quad$ Wang Jianzhong1, $\quad$ Li Qiang', Shang Jian', Cao Jianming1, \\ Xudong $^{2}$
}

${ }^{1}$ Liaoning University of Technology, Jinzhou 121001, China; ${ }^{2}$ Northeastern University, Shenyang 110004, China

\begin{abstract}
Mg}-\mathrm{Zn}$ alloys were prepared by a powder metallurgy method using Mg powder and $\mathrm{Zn}$ powder as starting materials. The effects of the $\mathrm{Zn}$ content on sintering density, microstructure, phase composition, bending properties and micro-hardness of the $\mathrm{Mg}-\mathrm{Zn}$ alloys were studied. The corrosion resistance of the $\mathrm{Mg}-\mathrm{Zn}$ alloys was also measured. The function mechanism of $\mathrm{Zn}$ element during the powder metallurgy process was analyzed. Results show that the sintered compacts have finer grain size and higher sintered density upon $\mathrm{Zn}$ addition. The density of the sintered products increases with the increasing of $\mathrm{Zn}$ content. XRD analysis shows that the Mg-3 wt $\% \mathrm{Zn}$ alloy is mainly composed of $\alpha-\mathrm{Mg}$ phase. When the content of $\mathrm{Zn}$ is $4 \mathrm{wt} \%$, the $\mathrm{Mg}$ - Zn alloys is composed of $\alpha-\mathrm{Mg}$ and $\mathrm{MgZn}_{2}$ phases. With the increase of the $\mathrm{Zn}$ content, the bending strength of the $\mathrm{Mg}-\mathrm{Zn}$ alloys first increases and then decreases, but the micro-hardness $\mathrm{HV}$ of $\mathrm{Mg}-\mathrm{Zn}$ alloys always increases. The bending strength and micro-hardness of Mg-3 wt $\% \mathrm{Zn}$ alloys are $123.6 \mathrm{MPa}$ and $1017 \mathrm{MPa}$, respectively, which are $58 \%$ and $45 \%$ higher than those of pure $\mathrm{Mg}$ samples. Corrosion resistance measurements show that the corrosion rate of the $\mathrm{Mg}-\mathrm{Zn}$ alloys decreases with the addition of $\mathrm{Zn}$ element, and the $\mathrm{Mg}-3 \mathrm{wt} \% \mathrm{Zn}$ alloy shows the lowest corrosion rate and the best corrosion resistance.
\end{abstract}

Key words: powder metallurgy method; $\mathrm{Mg}-\mathrm{Zn}$ alloy; $\mathrm{Zn}$ content; microstructure; property

Lightweight metals such as magnesium alloys are of increasing interests because of their potential applications in a lot of fields, such as transportation, aerospace and biomedical areas $^{[1]}$. The need to reduce weight to increase payload, and to minimize fuel consumption and the emission of the greenhouse gas $\mathrm{CO}_{2}$, have lead to a growing number of applications for magnesium alloys ${ }^{[2-4]}$. Furthermore, magnesium has been recently recognized as a promising biomaterial for bone substitution due to its excellent properties, e.g., a relatively low Young's modulus and a proper strength ${ }^{[5]}$, excellent biocompatibility ${ }^{[6,7]}$, biodegradability and bioresorbability ${ }^{[8,9]}$. However, $\mathrm{Mg}$ alloys prepared by common solidification generally show coarse microstructure and severe segregation, resulting in low corrosion resistance and mechanical properties at room temperature and high temperature ${ }^{[8,10]}$. As a result, these $\mathrm{Mg}$ alloys are difficult to satisfy the requirement for structural application requiring high properties, and thus their wider applications are restricted. Powder metallurgy technology is one of effective methods for preparing materials with high properties due to its excellent superiority of refining grain sizes, decreasing composition segregation and increasing solid solubility of alloy elements in the $\mathrm{Mg}$ matrix and forming metastable phase, which can greatly improve the mechanical properties and corrosion resistance behaviors. Since the mechanical properties and corrosion resistance of $\mathrm{Mg}$-alloys are affected by the combined effects of the alloy's chemical composition and its microstructure ${ }^{[11,12]}, \mathrm{Mg}-\mathrm{Zn}$ alloys were prepared by the powder metallurgy method in the present paper. The purpose is to

Received date: December 12, 2015

Foundation item: National High-Tech Research and Development Program of China ("863" Program) (2011AA060102); National Science Fund for Young Scholars (51405215); Natural Science Foundation of Liaoning Province (2014020111); High School Development Plan for Distinguished Young Scholars of Liaoning Province Education Committee (LJQ2013067); Project of Higher Education Innovation Team of Liaoning Province (LT2013014); Basic Research Project of Provincial Key Laboratory of Liaoning Education Department (LZ2014031)

Corresponding author: Yu Jingyuan, Ph. D., Associate Professor, College of Materials Science \& Engineering, Liaoning University of Technology, Jinzhou 121001, P. R. China, Tel: 0086-416-4199265, E-mail: yujingyuan79@163.com 
improve the poor corrosion behavior of commercial magnesium alloys added with $\mathrm{Fe}, \mathrm{Cu}$, Ni elements. The addition of $\mathrm{Zn}$ element has important effects on refining grain size and improving the mechanical properties and corrosion resistance of $\mathrm{Mg}$ alloys. In the present paper, the effects of $\mathrm{Zn}$ content on porosity, sintering shrinkage, microstructure, phase composition, bending properties and micro-hardness of $\mathrm{Mg}-\mathrm{Zn}$ alloys were studied. The corrosion resistance of $\mathrm{Mg}-\mathrm{Zn}$ alloys was measured. The function mechanism of $\mathrm{Zn}$ element during the powder metallurgy process was analyzed.

\section{Experiment}

$\mathrm{Mg}$ powder and $\mathrm{Zn}$ powder, both of purity $99.99 \%$, with particle size 74 and $37 \mu \mathrm{m}$, respectively, were used as starting materials. The morphologies of $\mathrm{Mg}$ and $\mathrm{Zn}$ powders are shown in Fig.1. The two powders were mixed at desired ratios and then pressed into rectangle green compacts $(50 \mathrm{~mm} \times 10$ $\mathrm{mm} \times 10 \mathrm{~mm}$ ) at the pressure of $100 \mathrm{MPa}$. The $\mathrm{Zn}$ content was changed from $0 \mathrm{wt} \%$ to $4 \mathrm{wt} \%$ in the green compacts. The cold compacted samples were heated to $893 \mathrm{~K}$ for $2 \mathrm{~h}$ in a furnace in Ar atmosphere. Microstructure of the specimens was analyzed using scanning electron microscopy (S-3000) on polished surfaces. Average size of $\mathrm{Mg}$ grains was measured by statistical analysis of the image on the several SEM photos. The sintering density of $\mathrm{Mg}-\mathrm{Zn}$ alloys was measured with Archimedes method. The phase structure was determined by $\mathrm{X}$-ray diffraction analysis (D/Max-2500/PC). Bending strength was measured using a universal testing machine (WDW-10) with a loading rate of $0.5 \mathrm{~mm} / \mathrm{min}$. The micro hardness was measured by a micro hardness tester (HVS-1000). The corrosion resistance was tested in $3.5 \mathrm{wt} \% \mathrm{NaCl}$ solution. The corrosion time was $24 \mathrm{~h}$. The corrosion rate was calculated

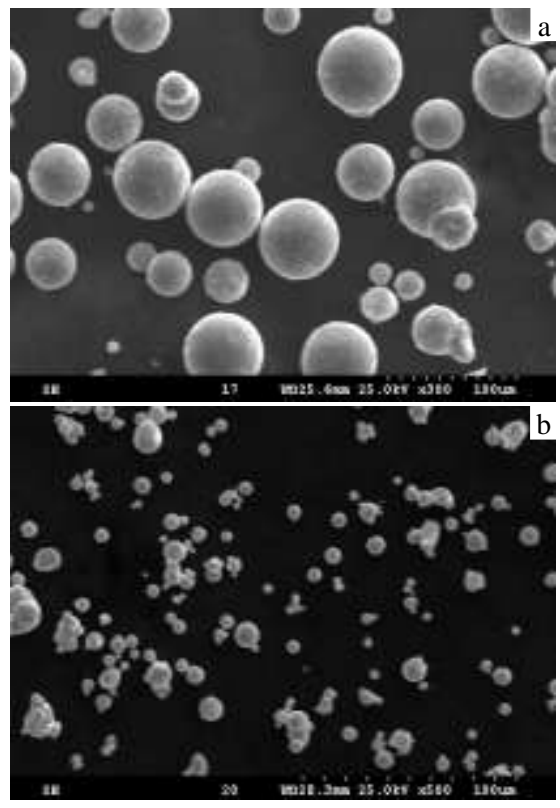

Fig.1 Morphologies of Mg (a) and $\mathrm{Zn}$ (b) powders by the following equation ${ }^{[13]}$ :

$$
v_{\mathrm{CORR}}=\frac{8.76 \times 10^{4}\left(W_{1}-W_{2}\right)}{A T D}
$$

where, $v_{\mathrm{CORR}}$ is corrosion rate $(\mathrm{mm} / \mathrm{a}), W_{1}$ is mass after corrosion $(\mathrm{g}), W_{2}$ is mass before corrosion $(\mathrm{g}), A$ is corrosive surface $\left(\mathrm{cm}^{2}\right), T$ is corrosive time (h), and $D$ is density of $\mathrm{Mg}$ alloys $\left(\mathrm{g} / \mathrm{cm}^{3}\right)$

\section{Results and Discussion}

\subsection{Effect of $\mathrm{Zn}$ content on sintering density of $\mathrm{Mg}-\mathrm{Zn}$ alloys}

Table 1 shows the sintering relative density of $\mathrm{Mg}-\mathrm{Zn}$ alloys with different $\mathrm{Zn}$ contents. The relative density of $\mathrm{Mg}-\mathrm{Zn}$ alloys increases from $97.2 \%$ to $99.1 \%$ when $\mathrm{Zn}$ content varies form 0 wt $\%$ to $4 \mathrm{wt} \%$. The reason for the enhanced density with $\mathrm{Zn}$ addition can be analyzed as follows. Although both $\mathrm{Mg}$ and $\mathrm{Zn}$ particles are of spherical shape, the average size of $\mathrm{Mg}$ particles is larger than that of $\mathrm{Zn}$ particles. When the two powders are mixed, the smaller $\mathrm{Zn}$ particles can fill into the intervals of the bigger $\mathrm{Mg}$ particles while in compaction, resulting in increasing green compact density. As a result, the diffusion distance between $\mathrm{Mg}$ and $\mathrm{Zn}$ particles becomes shorter, and the diffusion reaction of $\mathrm{Mg}$ and $\mathrm{Zn}$ particles proceeds more completely. Under these conditions, the samples are easy to be sintered to a denser microstructure. Furthermore, according to $\mathrm{Mg}-\mathrm{Zn}$ phase diagram, liquid phase formation is quite possible when $\mathrm{Zn}$ content is beyond $3 \mathrm{wt} \%$ at $893 \mathrm{~K}$, as shown in Fig. $2^{[14]}$. The diffusion rates of $\mathrm{Mg}$ and $\mathrm{Zn}$ particles may be greatly enhanced due to the involvement of liquid phase during sintering, resulting in higher density of sintered bodies ${ }^{[15]}$. It should be also noted that only minor increase of sintering density is observed when the content of $\mathrm{Zn}$ is beyond $3 \mathrm{wt} \%$.

Table 1 Sintering density of $\mathrm{Mg}-\mathrm{Zn}$ alloy with different Zn contents

\begin{tabular}{cccccc}
\hline Zn content/wt\% & 0 & 1 & 2 & 3 & 4 \\
\hline Density/\% & 97.2 & 97.8 & 98.5 & 99.0 & 99.1 \\
\hline
\end{tabular}

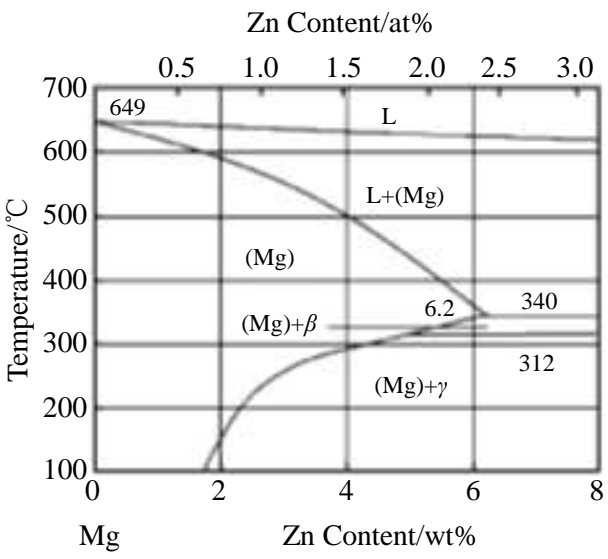

Fig.2 Phase diagram of Mg-Zn alloys 


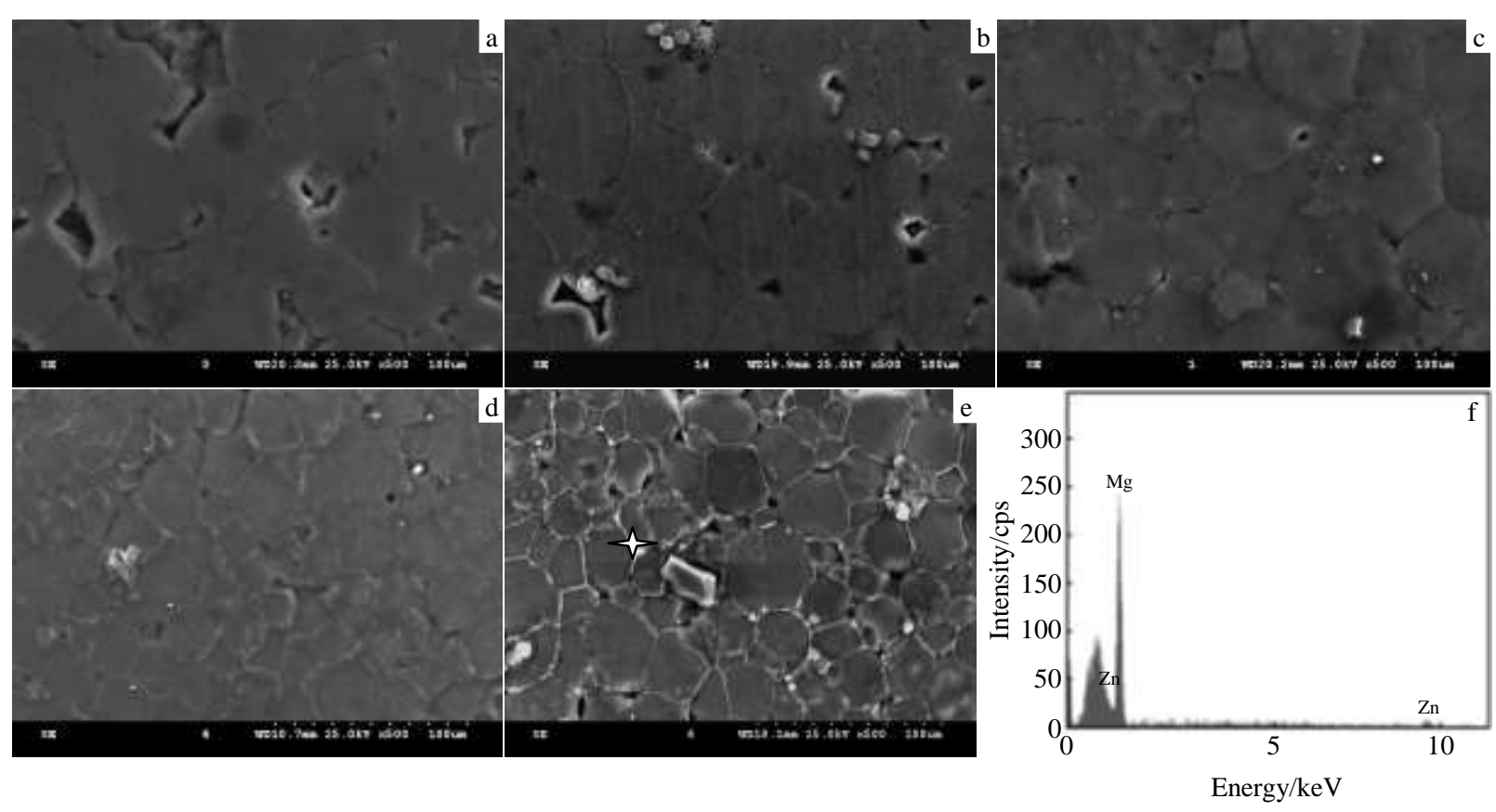

Fig.3 SEM images (a e) and EDS spectrum corresponding marked with the white asterisk in Fig.3e (f) of Mg-Zn alloys with different $\mathrm{Zn}$ contents: (a) $0 \mathrm{wt} \% \mathrm{Zn}$, (b) $1 \mathrm{wt} \% \mathrm{Zn}$, (c) $2 \mathrm{wt} \% \mathrm{Zn}$, (d) $3 \mathrm{wt} \% \mathrm{Zn}$, and (e) $4 \mathrm{wt} \% \mathrm{Zn}$

\subsection{Effect of Zn content on microstructure and phase structure of Mg-Zn alloys}

Fig. 3 shows the microstructures of the $\mathrm{Mg}-\mathrm{Zn}$ alloys with different $\mathrm{Zn}$ contents. As can be seen in Fig.3, with the increase of $\mathrm{Zn}$ content, the pore size of sintered compacts decreases, which is consistent with the results in Table 1. Besides, the grain sizes of the different $\mathrm{Mg}-\mathrm{Zn}$ alloys decrease form $37.8 \mu \mathrm{m}$ to $23.2 \mu \mathrm{m}$ when the $\mathrm{Zn}$ content increases form $0 \mathrm{wt} \%$ to $4 \mathrm{wt} \%$. The reason for the decreased grain sizes at high $\mathrm{Zn}$ content is as follows. First, $\mathrm{Mg}$ and $\mathrm{Zn}$ metals are both of close-packed hexagonal structure. The diffusion rate of $\mathrm{Zn}$ atoms in $\mathrm{Mg}$ matrix is faster than that of $\mathrm{Mg}$ atoms in $\mathrm{Zn}$ matrix. So $\mathrm{Zn}$ atoms can easily diffuse into $\mathrm{Mg}$ matrix and form the $\mathrm{Mg}$ solid solution or intermetallic compound. Fig.4 shows surface scanning images of $\mathrm{Mg}-\mathrm{Zn}$ alloys with $3 \mathrm{wt} \%$ $\mathrm{Zn}$ content. Comparing Fig. $4 \mathrm{a}$ and $4 \mathrm{c}$, it can be found that element $\mathrm{Zn}$ is mainly distributed on the surfaces of $\mathrm{Mg}$ grains, and no single particle of $\mathrm{Zn}$ element could be observed. Because the radius of $\mathrm{Zn}$ atom $(0.135 \mathrm{~nm})$ is smaller than that of $\mathrm{Mg}$ atom $(0.16 \mathrm{~nm})$, a tensile stress field at the distorted lattice of $\mathrm{Mg}$ matrix is expected when $\mathrm{Zn}$ atoms displace $\mathrm{Mg}$ atoms. There are gravitation forces between $\mathrm{Mg}$ and $\mathrm{Zn}$ atoms so $\mathrm{Mg}$ atoms are bounded by $\mathrm{Zn}$ atoms to some extent and the diffusion rate of $\mathrm{Mg}$ atoms decreases. The adjacent $\mathrm{Mg}$ particles are not easy to merge and grow up and their grain sizes become smaller. Comparing Fig.1a and Fig.3d, it is found that the grain size of $\mathrm{Mg}-3 \% \mathrm{Zn}$ alloys is very close to the size of initial $\mathrm{Mg}$ particles, indicating the effects of addition of $\mathrm{Zn}$ element in suppressing $\mathrm{Mg}$ grain growth. Furthermore, there are some white phase along the $\mathrm{Mg}$ grain boundary as can be seen in Fig.3d and 3e. The white phase along the grain boundary increases with the increase of $\mathrm{Zn}$ content. The EDS analysis of the white phase (marked with the white asterisk in Fig.3e) indicates a kind of $\mathrm{Mg}-\mathrm{Zn}$
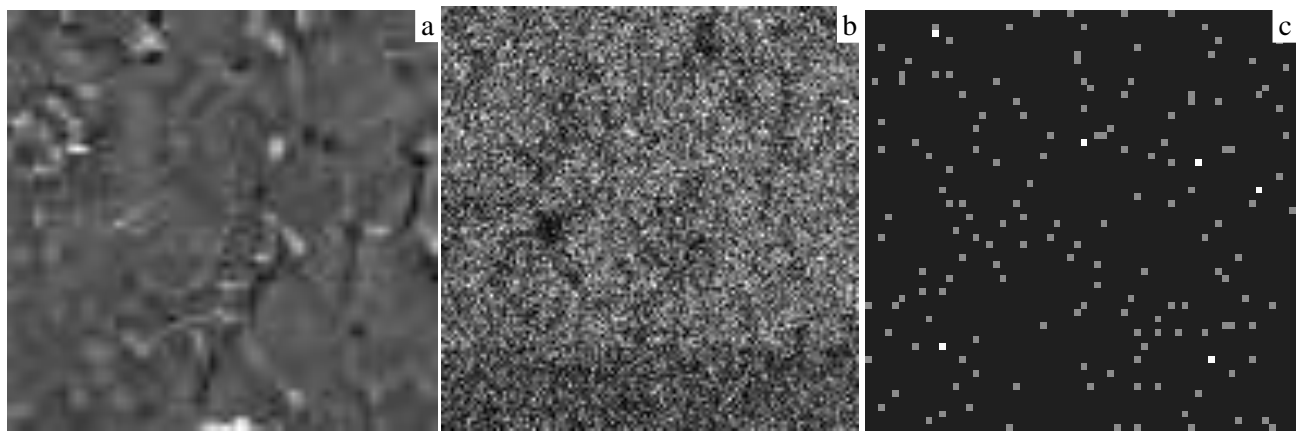

Fig.4 SEM surface morphology (a) and EDS analysis of element Mg (b), and element $\mathrm{Zn}$ (c) for Mg-3wt\% Zn alloy 
intermetallic compound, as shown in Fig.3f. It is known that the second phase along the grain boundary can hinder the movement of the grain boundary and suppress the grain growth. As a result, the refinement of the $\mathrm{Mg}$ grains is observed for the sample with high $\mathrm{Zn}$ contents.

Fig.5 shows XRD patterns of Mg-Zn alloys with $3 \mathrm{wt} \%$ and 4 wt $\% \mathrm{Zn}$. As can be seen in Fig.5, Mg-3wt\% Zn alloy is composed of single $\alpha-\mathrm{Mg}$ phase, and $\mathrm{Mg}-4 \mathrm{wt} \% \mathrm{Zn}$ alloy is composed of $\alpha-\mathrm{Mg}$ and $\mathrm{MgZn}_{2}$ phases. However, the existence of a little amount of $\mathrm{MgZn}_{2}$ (white phase along the $\mathrm{Mg}$ grain boundary) is also confirmed for the $\mathrm{Mg}-3 \mathrm{wt} \% \mathrm{Zn}$ alloy, as shown in Fig.3d. The reason for the different results of SEM and XRD analysis is that the total amount of $\mathrm{MgZn}_{2}$ at $\mathrm{Mg}-3$ $\mathrm{wt} \% \mathrm{Zn}$ alloy is less than $5 \%$, so it is not seen from XRD analysis. The reason of $\mathrm{MgZn}_{2}$ phase formation is as follows. With the increase of sintering temperature, the diffusion rates of $\mathrm{Mg}$ and $\mathrm{Zn}$ atoms in the adjacent particles increase. $\mathrm{Zn}$ atoms can easily diffuse into $\mathrm{Mg}$ matrix through sintering necks of $\mathrm{Mg}$ and $\mathrm{Zn}$ particles. The diffused $\mathrm{Zn}$ atoms usually stay near the sintering necks because of the limited diffusion ability of $\mathrm{Zn}$ atoms and the lattice distortion of $\mathrm{Mg}$ matrix. When the sintering necks transform into the grain boundaries, plentiful $\mathrm{Zn}$ atoms situate near the grain boundaries (which can be confirmed in Fig.4). At this time, the ratios of $\mathrm{Zn}$ and $\mathrm{Mg}$ atoms near the grain boundaries are much larger and satisfy the formation condition of $\mathrm{MgZn}_{2}$ phase.

\subsection{Effect of $\mathrm{Zn}$ content on bending strength and micro- hardness of $\mathrm{Mg}-\mathrm{Zn}$ alloys}

Table 2 shows the bending strength and microhardnesses of $\mathrm{Mg}-\mathrm{Zn}$ alloys with different $\mathrm{Zn}$ contents. From the table it is clear that the bending strength of $\mathrm{Mg}-\mathrm{Zn}$ alloys firstly increases and then decreases with the increase of $\mathrm{Zn}$ content. The reason is as follows. Firstly, the sintered compacts have higher densities, less pores and defects at high $\mathrm{Zn}$ contents, which can decrease the crack source and contribute to improvement of the bending strength of the compacts. Secondly, the lattice distortion resulting from the solution of $\mathrm{Zn}$ in $\mathrm{Mg}$ matrix can inhibit the dislocation motion and further improve the bending strength. Lastly, the smaller grain

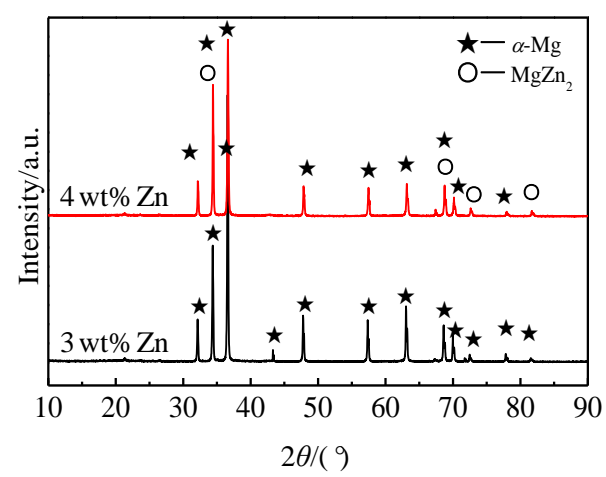

Fig.5 XRD patterns of $\mathrm{Mg}-\mathrm{Zn}$ alloys with $3 \mathrm{wt} \% \mathrm{Zn}$ and $4 \mathrm{wt} \% \mathrm{Zn}$
Table 2 Bending strength and microhardness of Mg- Zn alloys with different $\mathrm{Zn}$ contents

\begin{tabular}{ccc}
\hline $\begin{array}{c}\text { Zn content/ } \\
\text { wt } \%\end{array}$ & $\begin{array}{c}\text { Bending } \\
\text { strength/MPa }\end{array}$ & $\begin{array}{c}\text { Microhardness, } \\
\text { HV/MPa }\end{array}$ \\
\hline 0 & 78.2 & 695 \\
1 & 97.5 & 843 \\
2 & 111.7 & 952 \\
3 & 123.6 & 1017 \\
4 & 87.3 & 1057 \\
\hline
\end{tabular}

can increase grain boundary and decrease stress concentration. The surface increase and the twists of grain boundaries can hinder the crack propagation. So the bending strengths of $\mathrm{Mg}$ alloys increase at lower $\mathrm{Zn}$ contents, whereas the bending strength of $\mathrm{Mg}-\mathrm{Zn}$ alloys decreases when $\mathrm{Zn}$ content is at 4 $\mathrm{wt} \%$. This is because a lot of $\mathrm{MgZn}_{2}$ phases exist at the $\mathrm{Mg}$ grain boundaries and form coarse net structure (Fig.3e). When the cracks in $\mathrm{Mg}$ matrix are extended to the grain boundaries, the extension rate of the cracks increases because coarse $\mathrm{MgZn}_{2}$ net are hard and brittle. So the bending strength of the $\mathrm{Mg}-\mathrm{Zn}$ alloy with $4 \mathrm{wt} \% \mathrm{Zn}$ decreases.

The micro-hardness of $\mathrm{Mg}-\mathrm{Zn}$ alloys increases with increasing of $\mathrm{Zn}$ contents. This is because the sintered compacts have higher density, lower defects and proper lattice distortion at high $\mathrm{Zn}$ content. At the same time, the hard $\mathrm{MgZn}_{2}$ phases in the $\mathrm{Mg}-4 \mathrm{wt} \% \mathrm{Zn}$ alloys can contribute to the further improvement of the micro-hardness of the sintered compacts.

The bending strength and micro-hardness $\mathrm{HV}$ of sintered $\mathrm{Mg}-3 \mathrm{wt} \% \mathrm{Zn}$ alloy are $123.6 \mathrm{MPa}$ and $1017 \mathrm{MPa}$, respectively, which is $58 \%$ and $45 \%$ higher than those of pure $\mathrm{Mg}$ samples.

\subsection{Effect of $\mathrm{Zn}$ content on corrosion resistance of $\mathrm{Mg}$ - Zn alloys}

Fig.6 shows the corrosion rates of $\mathrm{Mg}-\mathrm{Zn}$ alloys with different $\mathrm{Zn}$ contents. As can be seen in Fig.6, the corrosion rate of pure $\mathrm{Mg}$ is the fastest. With the increase of $\mathrm{Zn}$ content, the corrosion rate of the $\mathrm{Mg}-\mathrm{Zn}$ alloy first decreases and then increases at the same corrosion time. The reason is that the corrosion potential of $\mathrm{Mg}(-2.37 \mathrm{~V})$ is much lower than that of $\mathrm{Zn}(-0.76 \mathrm{~V})$. The corrosion potential of $\mathrm{Mg}$ matrix increases

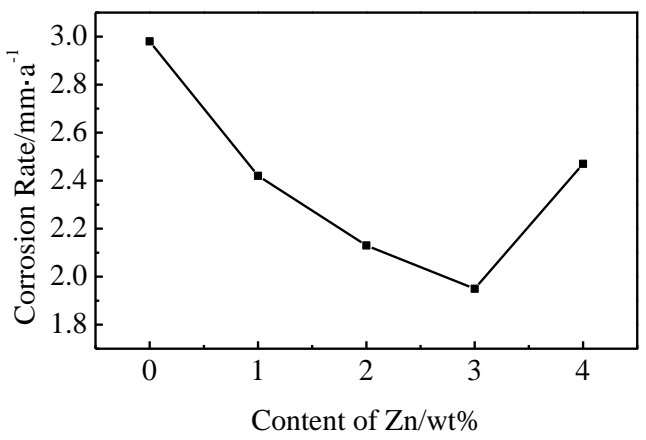

Fig.6 Corrosion rates of $\mathrm{Mg}-\mathrm{Zn}$ alloys with different $\mathrm{Zn}$ contents 


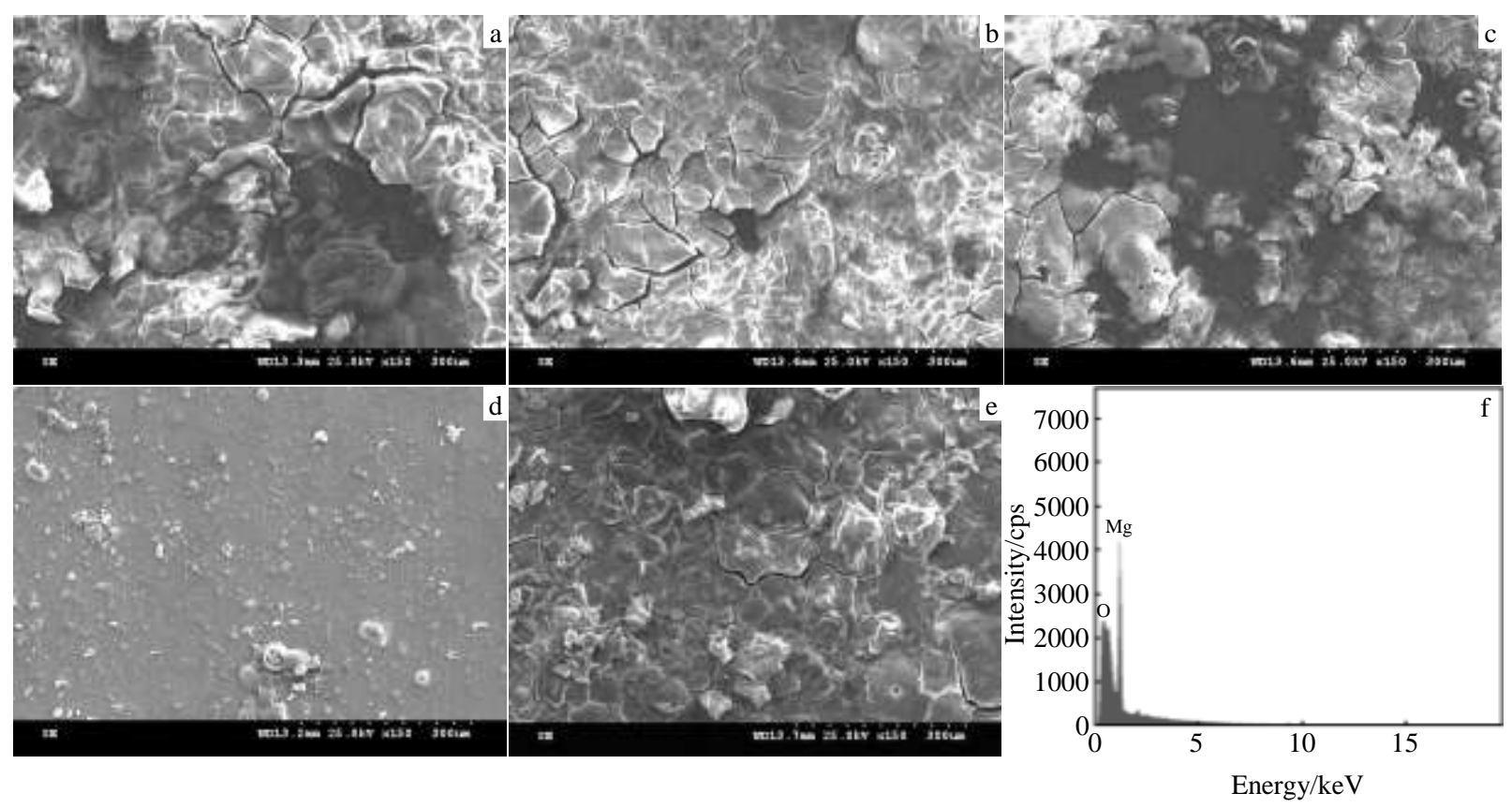

Fig.7 SEM images of Mg-Zn alloys with different Zn contents: (a) 0 wt $\% \mathrm{Zn}$, (b) $1 \mathrm{wt} \% \mathrm{Zn}$, (c) 2 wt $\% \mathrm{Zn}$, (d) 3 wt $\% \mathrm{Zn}$, and (e) $4 \mathrm{wt} \% \mathrm{Zn}$; (f) EDS spectrum of Mg-3wt\%Zn alloy

when $\mathrm{Zn}$ is dissolved in $\mathrm{Mg}$ matrix. Simultaneously, at high $\mathrm{Zn}$ content, the sintered compacts have higher density and corrosion resistance of the $\mathrm{Mg}-\mathrm{Zn}$ alloys. The increase of corrosion rate for alloy with $4 \mathrm{wt} \% \mathrm{Zn}$ can be attributed to the lower defects, which can contribute to the improvement of the occurrence of reticular $\mathrm{MgZn}_{2}$ phase along the $\mathrm{Mg}$ grain boundaries, which is a strengthening phase of cathode and can accelerate the corrosion of the $\mathrm{Mg}$ anode.

The corrosion rate of $\mathrm{Mg}-3 \mathrm{wt} \% \mathrm{Zn}$ alloy is $1.95 \mathrm{~mm} / \mathrm{a}$, which is $34.6 \%$ lower than that of pure $\mathrm{Mg}$ compact. $\mathrm{Mg}-3 \mathrm{wt} \% \mathrm{Zn}$ alloy has the best corrosion resistance.

Fig.7 shows microstructures and EDS analysis of the corroded surfaces of the $\mathrm{Mg}-\mathrm{Zn}$ alloys with different $\mathrm{Zn}$ contents. Pure Mg sample displays the worst corrosion surface, and the corrosive degrees of the $\mathrm{Mg}-\mathrm{Zn}$ alloys decrease at high $\mathrm{Zn}$ contents. Mg-3wt\%Zn alloys has less corrosion products on the surface and the corrosive degree is the slightest. The corrosive degree becomes more severe for $\mathrm{Mg}-4 \mathrm{wt} \% \mathrm{Zn}$ alloy as compared with $\mathrm{Mg}-3 \mathrm{wt} \% \mathrm{Zn}$ alloy because of a lot of reticular $\mathrm{MgZn}_{2}$ phase at the grain boundaries. Clearly, $\mathrm{Mg}-3 \mathrm{wt} \% \mathrm{Zn}$ alloy has better corrosion resistance. Fig.7f shows EDS analysis of the corrosive products of $\mathrm{Mg}-3 \mathrm{wt} \% \mathrm{Zn}$ alloy. There are elements $\mathrm{Mg}$ and $\mathrm{O}$ in the corrosive products, which shows the corrosive products on the surface of $\mathrm{Mg}-\mathrm{Zn}$ alloys are the oxide of $\mathrm{Mg}$.

\section{Conclusions}

1) The sintered $\mathrm{Mg}-\mathrm{Zn}$ alloys have higher density and smaller grain size at higher $\mathrm{Zn}$ content. $\mathrm{Mg}-3 \mathrm{wt} \% \mathrm{Zn}$ alloy is mainly composed of $\alpha-\mathrm{Mg}$ phase and $\mathrm{Mg}-4 \mathrm{wt} \% \mathrm{Zn}$ alloy is composed of $\alpha-\mathrm{Mg}$ and $\mathrm{MgZn}_{2}$ phases.

2) With the increase of $\mathrm{Zn}$ content, the bending strength of $\mathrm{Mg}-\mathrm{Zn}$ alloys firstly increases and then decreases, but the microhardness for different $\mathrm{Mg}-\mathrm{Zn}$ alloys continuously increases with the increasing of $\mathrm{Zn}$ content. The bending strength and micro-hardness $\mathrm{HV}$ of sintered $\mathrm{Mg}-3 \mathrm{wt} \% \mathrm{Zn}$ alloy are $123.6 \mathrm{MPa}$ and $1017 \mathrm{MPa}$, respectively, which is $58 \%$ and $45 \%$ higher than those of pure Mg samples.

3) The corrosion rates of $\mathrm{Mg}-\mathrm{Zn}$ alloys decrease when adding element $\mathrm{Zn}$ in $\mathrm{Mg}$ matrix. The corrosion rate of $\mathrm{Mg}-3 \mathrm{wt} \% \mathrm{Zn}$ alloy is $1.95 \mathrm{~mm} / \mathrm{a}$, which is $34.6 \%$ lower than that of pure $\mathrm{Mg}$ compact. $\mathrm{Mg}-3 \mathrm{wt} \% \mathrm{Zn}$ alloy has the best corrosion resistance.

\section{References}

1 Kainer K U. Magnesium Alloys and Technology[M]. Weinheim: Wiley-vch, 2003

2 Witte F, Fischer J, Beckmann F et al. Scripata Materialia[J], 2008, 58: 453

3 Tao Jianquan, Wan Yuanyuan, Sun Changjian et al. China Foundry[J], 2014, 10(4): 244

4 Chen Jun, Li Quannan, Li Jianghong et al. China Foundry[J], 2009, 6(2): 124

5 Gu X N, Zhou W R, Zheng Y F et al. Materials Letters[J], 2010, 64: 1871

6 Hao G L, Han F S, Li W D. Journal of Porous Material[J], 2009, 16(3): 251

7 Wang X, Li Y X, Liu Y. Materials Science and Engineering A[J], 2007, 444(1): 306

8 Kim S H, Kim D H, Kim N J. Material Science and 
Engineering[J], 1997, A226-228: 1030

9 Mordike B L, Ebert T. Materials Science and Engineering A[J], 2001, 302: 37

10 Shepelev D, Bamberger M, Katsman A. Journal of Materials Science[J], 2009, 44(20): 5627

11 Gao X, Zhu S M, Muddle B C et al. Scripta Materialia[J], 2005, 53(12): 1321

12 Oh J C, Ohkubo T, Mukai T et al. Scripta Materialia[J], 2005, 53(6): 675
13 Li J Q, Du C W. Corrosion Test Method and Monitoring Technology[M]. Beijing: China Petrochemical Press, 2007: 17 ( in Chinese)

14 Liu CM, Zu X F, Zou H T. The Phase Diagram Atlas of Magnesium Alloy[M]. Changsha: Central South University Press, 2006 ( in Chinese)

15 Zhou Y J, Yang H S, Liu J X. Hot Working Technology[J], 2013, 42(6): 15 ( in Chinese)

\title{
Zn 对粉末冶金法制备 Mg-Zn 合金组织与性能的影响
}

\author{
于景媛 ${ }^{1,2}$, 王建中 ${ }^{1}$, 李 强 $^{1}$, 商 剑 $^{1}$, 曹健铭 ${ }^{1}$, 孙旭东 ${ }^{2}$ \\ (1. 辽宁工业大学, 辽宁 锦州 121001) \\ (2. 东北大学, 辽宁 沈阳 110004)
}

\begin{abstract}
摘 要: 以 $\mathrm{Mg}$ 粉和 $\mathrm{Zn}$ 粉为初始原料, 采用粉末冶金技术制备 $\mathrm{Mg}-\mathrm{Zn}$ 合金。研究了 $\mathrm{Zn}$ 含量对 $\mathrm{Mg}-\mathrm{Zn}$ 合金烧结密度、显微组织、物相 组成、弯曲强度和显微硬度的影响。测量了 Mg-Zn 合金的耐腐蚀性, 探讨了 $\mathrm{Zn}$ 元素在粉末冶金过程中的作用机理。结果表明, 添加 $\mathrm{Zn}$ 元素后, 烧结产物的晶粒细小, 烧结密度提高。此外, 随着 $\mathrm{Zn}$ 含量的增加, 烧结产物的致密度持续增加。XRD 分析表明 Mg- $3 \% \mathrm{Zn}$ (质量分数)合金主要由 $\alpha-\mathrm{Mg}$ 相组成, 而 $\mathrm{Mg}-4 \% \mathrm{Zn}$ 合金由 $\alpha-\mathrm{Mg}$ 和 $\mathrm{MgZn}_{2}$ 两相组成。随着 $\mathrm{Zn}$ 含量的增加, $\mathrm{Mg}-\mathrm{Zn}$ 合金的抗弯曲强度 先增加而后降低, 但是显微硬度 $(\mathrm{HV})$ 持续增加。 $\mathrm{Mg}-3 \% \mathrm{Zn}$ 合金的抗弯强度为 $123.6 \mathrm{MPa}$, 显微硬度为 $1017 \mathrm{MPa}$, 分别比纯 $\mathrm{Mg}$ 样品 高出 58\%和 45\%。耐腐蚀性能测试表明当添加 $\mathrm{Zn}$ 元素后, $\mathrm{Mg}-\mathrm{Zn}$ 合金的腐蚀速率降低, Mg-3\% Zn 合金具有最低的腐蚀速率和最佳的 耐腐蚀性能。
\end{abstract}

关键词: 粉末冶金; Mg-Zn 合金; Zn 含量; 显微组织; 性能

作者简介: 于景媛, 女, 1979 年生, 博士, 副教授, 辽宁工业大学材料学院, 辽宁 锦州 121001, 电话: 0416-4164235, E-mail: yujingyuan79@ 163.com 